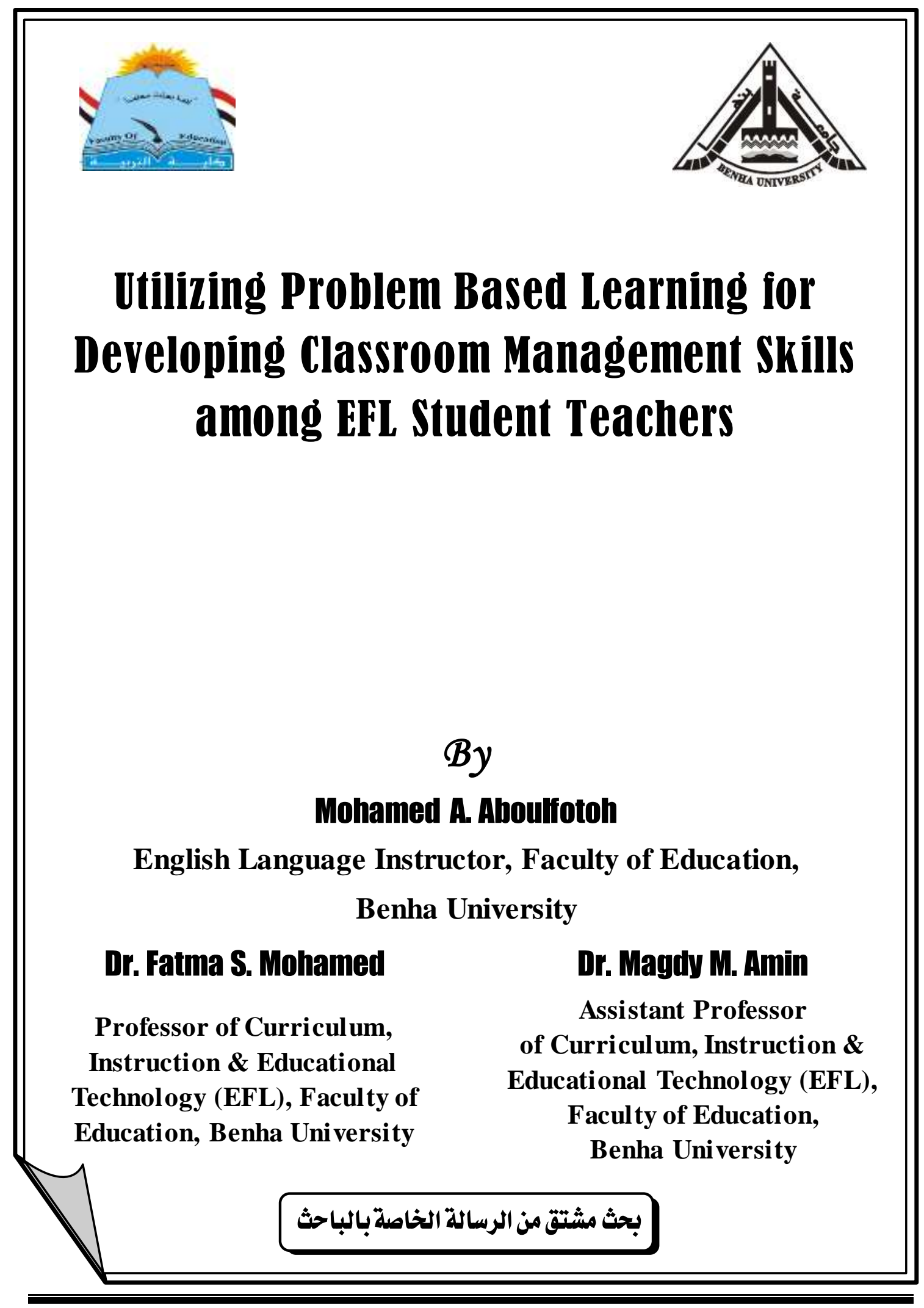




\section{Utilizing Problem Based Learning for Developing Classroom Management Skills among EFL Student Teachers}

\section{By \\ Mohamed A. Aboulfotoh}

English Language Instructor, Faculty of Education, Benha University

\section{Dr. Fatma S. Mohamed}

Professor of Curriculum, Instruction \& Educational Technology (EFL), Faculty of Education, Benha University
Dr. Magdy M. Amin

Assistant Professor of Curriculum, Instruction \& Educational Technology

(EFL), Faculty of Education, Benha University

\section{Ahstract}

The present research aimed at developing fourth year student teachers' EFL classroom management skills through Problem Based Learning (PBL). Participants of the research were selected from the fourth year student teachers at Faculty of Education, Benha University, in the academic year 2018/2019. They were randomly assigned into two groups: experimental $(n=30)$ and control $(n=30)$. The instruments of the research were a questionnaire of EFL classroom management skills, a pre-posttest of teaching knowledge of classroom management, a post classroom observation checklist and a reflection form. The research adopted the pre-posttest experimental/control group design. Results of the research revealed that the experimental group participants outperformed the control group in EFL classroom management skills. Thus, it is recommended to use the PBL in developing classroom management skills at the Faculties of Education in Egypt.

Keywords: Problem Based Learning, classroom management, student teachers.

\section{1}




\section{Research Problem and its Context}

\section{- Background of the Problem}

Teaching English takes place in a world of rapid developments that require the response to the real world. Teaching as a process includes the teacher, student, method and content. Of all of them, the teacher is the effective anchor to be developed professionally to meet the high standards of teaching and raise levels of achievement in schools. Developing EFL teachers' performance requires paying more attention to his or her classroom management (CM) skills especially in the stage of the student teacher preparation at the Faculties of Education in Egypt.

$\mathrm{CM}$ is a main teaching skill which is defined by Abu Al-Ghait (2007:35) and Stronge (2007:44) as a set of teacher's practices and activities to establish and maintain a positive interactive learning community that facilitates efficient students' learning. CM includes the ability to prevent negative behavior. These misbehaviors occur as students don't follow routines and procedures. Praising students, reinforcing positive behaviors and establishing trust in the classroom build respectful relationships between teachers and students. Reviewing more than 100 studies, Weinstein and Weber (2011:223) showed that positive teacher-student relationships are the key to effective $\mathrm{CM}$ and that such relationships actually reduce behavior problems by 31 percent.

Despite the importance of CM skills, Abdel-Hak (1997) revealed that student teachers complain about their inability in classroom management. Mueller and Skamp (2003, 428:440) have indicated that pre-service teachers face problems related to classroom management, understanding the ways students learn, working with colleagues, connecting the required work in courses and schools, as well as a host of other predicaments that can confront beginning teachers. Thus, Aly and Amin (2005, 21:22) have identified pre-service teachers' classroom management problems into top ten problems. Among these problems was the large number of pupils in the class, difficulty in dealing with 
trouble-makers and difficulty of applying what pre-service teachers have studied in the methodology course inside the classroom. EFL teachers were lenient in managing their classrooms and keeping order due to the extra focus of the preparation program on academic courses (linguistic) at the expense of experiential practice of teaching.

Miller (2008) examined learning contexts that can encourage preservice teachers to approach, reframe, and make sense of these problems. Rather than viewing pre-service teachers' problems as obstructive to learning and professional growth, a question that reframes pre-service teachers' inevitable challenges is "What happens to pre-service teachers' conceptions of teaching practice and student learning if their problems are used as a mechanism for their professional development (p.78)?" Hence, El Okda's study (2010) aimed at developing CM skills. The two main conclusions of the study were: first, methodology courses provided to student teachers of English should include a major component on classroom management. Second, care should be given to this important aspect in the classroom within the framework of task-based language teaching. From these conclusions, it is assured that pre-service teachers needed training in solving CM problems.

Moreover, active learning should be applied in teachers' preparation programs. Pepper, Blackwell, Monroe, and Coskey (2012:2) assured the role of active learning in these programs. Modeling active learning strategies has an influence on student teachers' later use of these strategies in their classrooms as practicing teachers. One of these active learning strategies is PBL. It provides student teachers with a learning context that relates between knowledge, skills and strategies in such a way that mirrors the real world through solving its problems which requires reflection, collaborative inquiry, self-regulation and self-directed learning.

From the pedagogical perspective, PBL is based on the constructivist theory of learning (Savery \& Duffy, 1995: 31). It exposes student teachers to the complex situations which they will encounter and 
captures the essence of constructivist and social constructivist learning theories (Peters, 2006: 27). In PBL, teachers acquire knowledge through engaging with authentic problems and operate in small groups to solve those using resources available to them (Hmelo-Silver \& Barrows, 2008: 94). PBL is an active learning strategy as student teachers are engaged in designing problems. Each problem cycle concludes with a reflection phase (Walker \& Leary, 2009: 43). PBL is designed to foster the intentional professional development of the student teachers (Brears, MacIntyre \& O'Sullivan, 2011:2).

\section{- Context of the Problem}

According to the specification of "English Methodology 2" course for the fourth year student teachers at Benha Faculty of Education, one of the main aims of the course is to help them be able to manage classrooms effectively.

Despite the importance of EFL classroom management skills, there was a weakness in them among fourth year student teachers enrolled in the English section, Benha Faculty of Education. The problem was assured by the results of these studies: Abdel-Hak (1997); Abdel Halim (2008); Abu Al-Ghait(2014) and Abd El-Razek,(2015). Surveying these studies, it was concluded that: (1). Student teachers have a low level in their classroom management and (2). They need active learning strategies such as PBL to reflect on their problems in a systematic way.

To document the problem of the research, an observation checklist was applied to (20) EFL student teachers of fourth year in the first term 2015/2016, at Benha Faculty of Education. The aim of the checklist was to evaluate EFL classroom management skills among the fourth year student teachers. The checklist was adopted from Kyriacou, (2007, 11:13). The "Chi-Square" was used to identify the mean of teaching performance level among the fourth year student teachers' classroom management. It was found that there were no differences between the observed and expected frequencies of fourth year student teachers' scores in their classroom management skills. This signifies that there is a weakness in their EFL classroom management skills. 
- Problem of the Research

The problem of this research was "the low level of EFL classroom management skills among the fourth year student teachers, English section at Faculty of Education, Benha University". Thus, PBL is presented to face the problem.

\section{- Questions of the Research}

To tackle the problem, this research attempted to answer the following questions:

1- What are the EFL CM skills needed for the fourth year student teachers?

2- What is the effectiveness of Problem-Based Learning in developing EFL CM skills among the fourth year student teachers?

\section{- Hypothesis of the Research}

The hypothesis stated that "there is a statistically significant difference between the mean scores of the experimental group and the control group of "Classroom Management Skills" in the posttest of teaching knowledge at the level of $\alpha 0.05$, in favor of the experimental group"

\section{- Delimitations of the Research}

The research was limited to the following:

- A group of fourth year student teachers, English section at Faculty of Education, Benha University

- Some EFL classroom management skills needed for fourth year student teachers, English section at Faculty of Education, Benha University

\section{- Instruments of the Research}

To achieve the aims of the research, the instruments were as follows:

- A questionnaire of CM skills, prepared by the researcher

- A Pre-Post Test of Teaching Knowledge of CM, prepared by the researcher

- A Post Classroom Observation Checklist, prepared by the researcher

- A Reflection Form, prepared by the researcher 


\section{- Participants of the Research}

The participants consisted of two groups: a control group and an experimental one of fourth year student teachers, English section at Faculty of Education, Benha University. The fourth year student teachers had been selected as it is expected that they acquired the minimum level of the required teaching knowledge and skills to complete a certain instructional program.

\section{- Significance of the Research}

It was hoped that this research would be useful for:

- Student teachers as it will help develop their EFL classroom management skills.

- Curricula and training program designers as it will provide them with a guide for using PBL when developing and designing EFL training course.

\section{- Terminology}

\section{Problem-Based Learning (PBL)}

Tan (2009: 206) defined PBL as a learner-centered strategy where unstructured (real-world) problems are used as the starting point for the learning process.

Savin-Baden (2014: 210) defined PBL as a "liquid learning" -in the sense that learning and knowledge are always on the move ... within and beyond disciplinary areas(p.210)".

The operational definition of PBL is "an experiential learning in which real teaching problematic situations are the instructional materials that motivate student teachers to acquire knowledge and skills through collaborative inquiry, reflection, self-directed, and self-regulated learning".

\section{Classroom Management Skills(CM)}

$\mathrm{CM}$ refers to the actions teachers take to create a respectful, caring, orderly, and productive environment (Weinstein \& Weber, 2011,2017:222). 
The operational definition of classroom management skill is "creating an effective learning environment including physical design, rapport, communication, addressing students' needs and characteristics, keeping order and discipline, and preventing negative behaviors".

\section{- Review of Literature and Related Studies}

\section{Classroom Management (CM)}

$\mathrm{CM}$ is maintaining positive communication, controlling behavior, and creating a positive learning climate. It includes skills of communication whether verbal or nonverbal (Abu Al-Ghait, 2007:3). Regarding CM skill, teachers first think about designing the physical environment. Planning of the physical environment begins before the school year starts and supports instruction (Weinstein \& Weber, 2011:222).

Most beginning teachers are not able to control their students and that would impede effective instruction. The major reason for this lack has been that educators formerly have a poor systematic understanding of classroom dynamics; while the purpose of teaching is to stimulate desired student learning, the purpose of CM is to establish the conditions that best promote student learning (Copper, 2011:1).

Weinstein and Weber (2011:215:218) have illuminated the challenges facing teachers with respect to CM. Classrooms are either crowded or complex environments. Within this environment, the teacher has to attend to students' needs with different levels of achievement, interests, and attitudes toward the content. Student teachers have despaired over students who constantly talk, text message in the back of the class, come late, bully and harass their peers, and are disengaged, or disruptive. Hence, student teachers need "real life stories on how to resolve classroom management issues" and decry courses that are too theoretical.

Therefore, CM. should be set up before lesson presentation. It includes the physical design, rapport, effective communication, managing the students' misbehaviors and addressing their needs and characteristics. Effective teachers should establish first the class protocol or routines inside the class then present the lesson. 


\section{- Problem Based Learning(PBL)}

Implementing PBL is an interrelated process that balances the student teachers' needs and the curriculum within a particular learning context through these steps:

1- A Problem Design: The Scenario: Tutors select problematic situations, knowing student teachers' needs (Filipenko \& Naslund, 2016: 63).

2- A Problem Presentation: Student teachers are given the "problem" that presented in a number of ways identified by Papageorgiou, McCrorie, Georgiades and Perdikogianni (2015:20) as a case, photograph, film, an article from a professional journal or newspaper, and a real or simulated teacher. Pre-service teachers undertake the PBL in small groups (7-10). Each group or team has a leader. Choo(2012:168) outlined the stages of PBL in the following diagram:

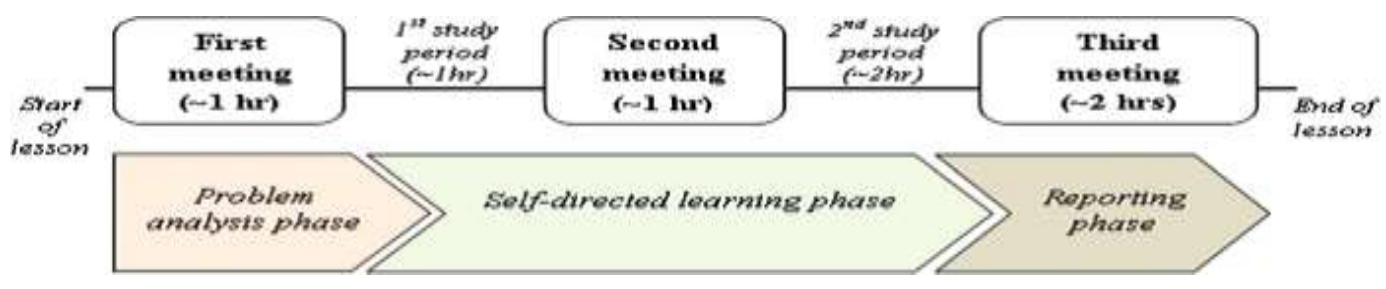

Figure (1): Schematic Diagram Illustrating an Overview of the PBL(Choo, 2012: 168)

3- First meeting (Problem analysis phase): Student teachers are given approximately 10 minutes to share their initial response to the problem in teams. Through group discussions, they fill up what we call a Problem Definition Template (PDT) as a scaffolding tool, identifying what they knew, do not know and need to find out to address the problem (Grady, Yew, Goh \&Schmidt, 2012:7).

Throughout the discussion, student teachers formulate learning issues or questions which they write up on the whiteboard or flipchart. The next step is self-study (Papageorgiou, McCrorie, Georgiades \& Perdikogianni,2015,24: 25). By the end of the first meeting, they identify these gaps as learning issues to be studied further during the self-directed learning phase (first study period) (Grady, Yew, Goh \& Schmidt, 2012: 8). 
- First study period (Self-Directed Learning Phase): After the first meeting, student teachers are given about an hour to carry out individual self-study and to work in their teams. They are provided with a learning scaffold in the form of a 'worksheet'. By the end of the first study period, each team would be expected to answer at least in part, some of the questions raised in their PDT earlier (Grady; Yew, Goh \&Schmidt, 2012: 9).

4- Second meeting: The facilitator returns to the class during the second meeting to meet the teams. The facilitator helps them with their learning difficulties or facilitate building their conceptual understanding.

- Second study period (Self-directed Learning Phase): After their discussion with the facilitator, the teams continue their selfdirected study as a team discussion to consolidate their findings and formulate a response to the problem. What is important is that student teachers develop a learning artifact that they can use along with a verbal explanation to demonstrate their understanding (Choo, 2012: 169).

5- Third meeting (Reporting Phase): During the third meeting (reporting phase), each team presents their consolidated findings and response to the problem, elaborating, justifying and defending based on questions raised by peers and the facilitator (Grady; Yew, Goh \&Schmidt, 2012: 10).

6- Reflection on the learning process: At the end, student teachers reflect on knowledge and skills acquired by completing a reflection journal.

Due to the importance of Problem Based Learning in developing EFL classroom management skills, some studies dealt with them; as Cassarino (2006) investigated the impact of PBL on critical thinking and problem solving skills. The results of the qualitative data indicated that PBL when applied to group work develops social abilities, technology dependencies and problem solving strategies. Avci, Akinci and Bakioglu(2012) designed an education program in the light of a problem based learning in classroom management and determine students' opinion on the exercise. The prospective teachers stated that they felt themselves to be more competent in terms of CM; and they would be able to find solutions should they encounter similar problems in the future. 


\section{Method}

\section{- Participants of the Research}

The participants were (60) student teachers randomly selected at Faculty of Education, Benha University, enrolled in the fourth year, English Section which was the final stage at the Teacher Preparation Program. They were divided into two groups, one was control $(\mathrm{n}=30)$ and the other was an experimental group $(n=30)$.

\section{- Setting of the Research}

The research was applied to the fourth year student teachers, English Section in the Information Technology Unit (ITU) at Faculty of Education, Benha University.

\section{- Instruments of the Research}

To achieve the purpose of the research, the following instruments were used: a questionnaire of some EFL classroom management skills, a pre-posttest of teaching knowledge of classroom management, a post classroom observation checklist and a reflection form

\section{- A Questionnaire of some EFL Classroom Management Skills Description of the Questionnaire}

The questionnaire of EFL classroom management sub- skills included (7) items. Each item was in three-Point-Likert format for identifying if it was "Very Important = 3"; "Somewhat Important = 2"; and "Less Important $=1$ " by ticking $(\sqrt{ })$ in the space provided. At the end of the questionnaire, there was a part for the jury's suggestions.

The items of the questionnaire were based on the survey of literature: (Cooper, 2011; and Breeze \& Guinda, 2017) and the studies of EFL classroom management skills: (Aly \& Amin, 2005; Abu Al-Ghait, 2014; Abd El-Razek, 2015; Ali, 2016; Taha, 2017 and Yousef, 2017)

The questionnaire of some EFL classroom management skills was presented to a panel of jury of EFL Curriculum and Instruction $(n=10)$. Modifications were made concerning rephrasing some items. One item was deleted based on the opinion of the jury members. Thus, the final form of the questionnaire included 6 items. 


\section{- A Pre-Post Test of Teaching Knowledge of Classroom} Management

The initial form of the test included four questions in which student teachers were asked firstly to state how the physicaldesign affects students' behavior directly or indirectly (4 items). Secondly, place the code letters of the classroom management approach that each situation represents in the space provided (10 items). Thirdly, Match students' needs \& characteristics in column (A) with its equivalent in column(B) (8 items). The fourth was to decide how they perceive the classroom problems by placing $(\sqrt{ })$ in the provided space, then suggest the possible solution (4 items).

The final form of the test included five questions in which student teachers were asked firstly to state the effect of seating on the students' behavior (4 items); secondly, select the classroom management style that represent the situation ( 8 items); thirdly, complete the statements (4 items); the fourth was to decide how to perceive the classroom problems and suggest the best solution (4 items) and the fifth was "true" or "false" question (4 items).

The test was prepared in the light of the questionnaire of some appropriate EFL classroom management sub-kills for the fourth year student teachers refereed by the jury's members and reviewing the literature concerning the assessment of teaching knowledge, e.g. (Cooper, 2011; and Spratt, Pulverness \& Williams, 2011) in addition to the study of (Abdel Halim, 2008 and Hammam, 2016).

To determine the validity of the test, it was submitted to a panel of jury $(\mathrm{N}=10)$ of $\mathrm{EFL}$ experts in Curriculum and Instruction. They were requested to read the test items and give their suggestions concerns the following:

1- Were the test items appropriate for the fourth year student teachers' level?

2- Were the test items appropriate and sufficient to measure some EFL teaching knowledge of classroom management?

The test was approved by the jury with the following recommendations:

1- Decreasing the number of the test items: four ones instead of five. 
2- Varying the type of questions using complete, true or false...etc, Thus, question n. 3 in classroom management: "Match students' needs and characteristics in column (A) with its equivalents in column (B)" was rephrased in the form: "complete the following statements"

\section{- Piloting the Test}

The participants chosen for piloting the test were (23) student teachers, other than those of the experimental and control group, selected from the fourth year, English Section at Faculty Education, Benha University in the academic year 2017/2018. To estimate the test time, the time taken by the fastest student teachers $(20 \mathrm{~min}$.) was added to the time taken by the slowest ones $(40 \mathrm{~min}$.) then divided by two. It was estimated that 30 minutes would be enough to answer the test.

\section{- Scoring the Test}

The total score of the test was (24). Each item was marked out of (4). The objectivity of marking was achieved as follows: if the student teacher gives the right answer, he/she will take four scores but if not, he/she will take zero. The test was administered on the $5^{\text {th }}$ of April, 2018 to a randomly chosen group of twenty-three of fourth year student teachers, other than the participants of the experiment. Then, it was administrated again after two weeks to the same group of student teachers on the $22^{\text {th }}$ of April, 2018. The Cronbach's Alpha was 0.94 which is highly reliable.

\section{The Post Classroom Observation Checklist}

The post classroom observation checklist consisted of six teaching behaviors or indicators which were determined by the panel of jury members in the questionnaire of CM skills.

The total score of the post classroom observation checklist was calculated by adding the numbers associated with performance to each behavior. As the checklist ranged from 1 to 3 . Thus, the highest score was 18 and the lowest was 3 .

\section{- The Reflection Form}

The Reflection Form consisted of eight questions that determined student teachers' experience before and after the PBL treatment. These questions were:

1- What knowledge did you learn through PBL? 
2- What skills did you have through PBL?

3- How do you relate theory to practice through PBL?

4- Does PBL program develop your teaching performance? How?

5- Do you think that PBL develop your self-confidence to achieve your tasks as an effective teacher?

6- Will you use PBL to solve teaching problems in the future?

7- Give an experience / a story or an applicable example briefly on using PBL in your class.

8- Describe your teaching experience before \& after the PBL program (teaching knowledge, skills, view about yourself as a teacher, and self-confidence)

\section{- The Treatment of Problem Based Learning (PBL)}

\section{Pre-Testing}

To make sure that the level of both groups (experimental and control) was equivalent (homogeneous) in EFL classroom management skills, the pre-post Teaching Knowledge Test of classroom management was administered to them before implementing the Problem-Based Learning Program. The means, standard deviation and t-value of the two groups were computed.

Table [1]: Findings of " $t$ " test between the experimental and the control group of EFL classroom management skills in the pre-assessment

\begin{tabular}{||c|c|c|c|c|c|c|c||}
\hline Skill & Group & N & Mean & S.D & t-Value & D.F & Sig. \\
\hline \hline $\begin{array}{c}\text { Classroom } \\
\text { Management }\end{array}$ & Exp. & 30 & 14.30 & 3.07 & \multirow{2}{*}{3.52} & 74 & .005 \\
\cline { 2 - 9 } & Cont. & 30 & 11.01 & 4.87 & & & \\
\hline \hline
\end{tabular}

Table [1] indicates that there was no statistically significant difference between the mean scores of the two groups in EFL classroom management skills in the pre-posttest, where t-value is (3.52), which is not significant at (0.05). Thus, the two groups were equivalent in their EFL classroom management skills.

In order to investigate the effectiveness of the PBLP in developing some EFL classroom management skills among fourth year student 
teachers at Faculty of Education Benha University, a framework of the PBL was prepared and outlined. The treatment of PBL handled the specified EFL classroom management skills. Student teachers reflected on their performance of classroom management in the practicum. They gave a list of problems to devise solutions or strategies. The instructor's or tutor's manual was designed according to the procedures of PBL.

\section{- Post - Testing}

On the $13^{\text {th }}$ of Dec. 2018, the post-test was administered to both the control and the experimental groups. For high level of objectivity, the control group's sheets and the experimental group's sheet (both in pre and posttest) were mixed together and given serial numbers. Sheets were left without any mark whether they were: control or experimental, pre or post. Only the serial numbers appeared. Finally, data was collected.

\section{Resulits of the Research}

\section{- Validating the Hypothesis}

The hypothesis stated that "there is a statistically significant difference between the mean scores of the experimental group and the control one of "classroom management skills" in the post-assessment at the level of $\alpha 0.05$, in favor of the experimental group".

Table [4] presents t-value and the level of significance of both experimental and the control one of "classroom management" skill in the post- assessment.

Table [2]: Findings of " $t$ " test between the experimental group and the control one of classroom management skills in the post-assessment

\begin{tabular}{|c|c|c|c|c|c|c|c|}
\hline Skill & Group & N. & Mean & S.D & T-Value & D.F & Sig. \\
\hline \hline $\begin{array}{l}\text { Classroom } \\
\text { Management }\end{array}$ & Exp. & 30 & 20.26 & 1.55 & \multirow{2}{*}{22.94} & 58 & $\mathbf{0 . 0 5}$ \\
\cline { 2 - 8 } & Cont. & 30 & 12.26 & 1.11 & & & \\
\hline
\end{tabular}

Table [2] demonstrates that there is a statistically significant difference between the mean scores of the experimental group and the control one of classroom management skills in favor of the experimental group in the post-assessment, where t-value is (22.94) which is 
significant at the (0.05) level of significance. Therefore, this hypothesis was accepted. This finding is consistent with the studies of Cassarino (2006) and Avci, Akinic and Bakioglu (2012).

- The size of the effectiveness of the PBL $\left(n^{2}\right)$ in developing EFL classroom management skills for the experimental group student teachers in the pre/post-assessment.

Table [3]: Findings of the PBL $\left(\eta^{2}\right)$ in developing EFL classroom management skills for the experimental group student teachers in the pre/post-assessment

\begin{tabular}{|c|c|c|c|c|c|c|c|}
\hline Assessment & Group & N. & Mean & S.D & t-value & D.F & $\boldsymbol{\eta}^{2}$ \\
\hline \hline Pre-post TKT & Exp. & 30 & 32.90 & 3.88 & 46.33 & 29 & 98.66 \\
\hline $\begin{array}{c}\text { Post observation } \\
\text { checklist }\end{array}$ & Exp. & 30 & 13.16 & 5.09 & 14.14 & 29 & 87.33 \\
\hline
\end{tabular}

Table [3] indicates that the " $\boldsymbol{\eta}^{2 \text { " }} \mathbf{s}$ ' of the PBL are (98.66) for teaching knowledge of classroom management, and (87.33) for post observation checklist in the post- assessment. This signifies that the PBL is more effective in developing EFL classroom management skills among fourth year student teachers.

\section{- Discussion of the Results}

The aim of the present research was to develop EFL classroom management skills among the fourth year student teachers using the PBL. The PBL helped student teachers reflect on their teaching experiences in real contexts /classrooms. They identified their teaching problems using strategic thinking. They became self-directed learners, searching information from different resources, locating potential useful information, sharing it and collecting it to complete the whole picture of the situation. They negotiated with each other's, organizing their roles, shared their knowledge, selected the appropriate solving strategy, solved the problem, modelled the solution and reflected on the whole experience. Thus, using the PBL developed the experimental group student teachers' classroom management skills than the control group in the post- assessment. This result was consistent with the results of many previous studies (Elbassuony, 2011; Vogel, 2014; Abd El-Gawad, 2016 and Ali, 2016) 


\section{- Conclusions}

The main conclusion was that PBL was effective in developing EFL classroom management skills among fourth year student teachers at Faculty of Education, Benha University.

\section{Recommendations}

In the light of previous results, the following recommendations could be presented:

- PBL and problem solving strategies should be used in developing EFL classroom management skills at the Faculties of Education in Egypt.

- The fourth year student teachers should demonstrate their ability for inquiry skills; e.g. reflection, self- directed learning, selfregulating, ...etc.

- The fourth year student teachers should focus on their higher order thinking skills e.g. analysis, synthesis, evaluation, and application, etc. not only recalling information.

\section{- Suggestions for Further Research}

Based on the findings of the present research, the followings are implications for further research:

- Investigating the effectiveness of the Problem Based Learning in improving classroom management skills and teaching self-efficacy among student teachers.

- Investigating the effectiveness of the Problem Based Learning in developing teachers' EFL classroom management skills and its relation to students' EFL language performance skills. 


\section{References}

Abd El-Gawaad, R. (2016). The effectiveness of virtual learning environment in developing teaching efficiency of Basic Education Student Teachers of English. Ph.D. Dissertation, Faculty of Education, Assiut University

Abdel-Hak, I. (1997). Investigating EFL teaching practice problems from the student teachers', supervisors' and co-operative teachers' view point. Journal of Mansoura Faculty of Education, N. 35

Abdel Halim, S. (2008). The effect of using some professional development strategies on improving the teaching performance of English language student teacher at the faculty of Education, Helwan University in the light of pre-service teacher standards. Ph.D. Dissertation, Faculty of Education, Helwan University

Abd El-Razek, S. (2015). The effectiveness of a program based on professional development strategies in developing some professional skills of prospective teachers of English. Ph.D. Dissertation, Faculty of Education, Port-Said University

Abu Al-Ghait, R. (2007). A Proposed Training Program Based on the Contemporary World Standards for Developing Some EFL Teaching Skills for the Student Teachers at the College of Education. Unpublished Master' Thesis, Faculty of Education, Mansoura University.

Abu Al-Ghait, R. (2014). The Effectiveness of a Proposed Program in Electronic Assessment on Developing EFL Teaching Skills for Student Teachers at Faculties of Education. Ph.D. Dissertation, Faculty of Education, Mansoura University

Ali, A. (2016). The Effectiveness of a Program Based on the Modified Sheltered Instruction Observation Protocol Model (SIOP) in Developing Teaching performance, Self-Assessment and Sense of Teacher Efficacy of Teachers of English. Ph.D. Dissertation, Faculty of Education, Assiut University 
Aly, M. \& Amin, M. (2005). Student teaching problems as perceived by the English language pre-service teachers. Benha Faculty of Education Journal, No.104

Avci, S.; Akinci, T. \& Bakioglu, A. (2012). Using real life problems for developing prospective teachers' classroom management skills. Cukurova University, Faculty of Education journal, Vol. 41, N.2, pp.18:28. Available at: http://search .proquest.com/docview. ProQuest Education Journals. Retrieved on:15 December, 2014

Brears, L.; MacIntyre, B. \& O'Sullivan, G. (2011). Preparing teachers for the 21st century using PBL as an integrating strategy in Science and Technology Education. Massey College of Education, New Zealand. Design and Technology Education, Vol.16, N.1, pp36-46. Eric EJ 916495. Retrieved on:15 December, 2015

Breeze, R. \& Guinda, C. (2017). Essential Competencies for English-medium University Teaching. Switzerland: Springer International Publishing

Cooper, J. (2011). Classroom Teaching Skills. $9^{\text {th }}$ edition. USA: Wadsworth, Cengage Learning

Cssarino, C. (2006). The impact of problem-based learning on critical thinking and problem solving skills. Nova Southeastern University, ProQuest, UMI Dissertation no 3233901

Choo, S. (2012). Scaffolding in Problem-based Learning. In Grady, G.; Yew, E. \&Schmidt, G. (2012). One-Day, One-Problem: An Approach to Problem-based Learning. Singapore. Springer Science+Business Media

Cheng, C. (2013).Enhancing the qualityof pre-service teachers' learning in teaching practicum.The Hong Kong Institute of Education, Hong Kong, China,eckcheng@ied.edu.hk

El-bassuony, J. (2011).Using collaborative action research and Facebook to develop EFL pre-service teachers' professionalism in the light of STEPS standards. Studies in Curriculum and Instruction, Vol.176, Pp.1-48 
El-Okda, H. (2010). A proposed framework for Prep Stage EFL teachers' performance professional development in the light of their needs. MA. Thesis, Institute of Educational Studies, Cairo University

Filipenko, M. \& Naslund, J. (2016). Problem-Based Learning in Teacher Education. New York : Springer International Publishing Switzerland

Grady, G.; Yew, E.; Goh, K. \& Schmidt, G. (2012). One-Day, OneProblem: An Approach to Problem-based Learning. Singapore. Springer Science+ Business Media.

Hammam, E. (2016). Developing EFL student teachers' classroom performance skills and teaching self-Efficacy through CoTeaching. MA. Thesis, Faculty of Education, Menoufia Univesity

Hmelo-Silver, C. \& Barrows, H.(2008). Facilitating collaborative knowledge building. Cognition and Instruction, Vol. 26, N. 1, pp. 48-94.

Kyriacou, C. (2007) Essential teaching skills. $3^{\text {rd }}$ edition. United Kingdom: Nelson Thornes Ltd

Miller, M. (2008). Problem-Based Conversation: Using pre-service teachers' problems as a mechanism for their professional development. Teacher Education Quarterly. On Eric EJ838702

Mueller, A., \& Skamp, K. (2003) Teacher candidates talk: Listen to the unsteady beat of learning to teach. Journal of Teacher Education, vol. 54, N. 5, pp. 428-440

Papageorgiou, A.; McCrorie, P.; Georgiades, S.; \& Perdikogianni, M. (2015). Psychology for Psychologists: A Problem Based Approach to Undergraduate Psychology Teaching.UK: Palgrave Macmillan

Pepper, K.; Blackwell, S.; Monroe, A.; and Coskey, S. (2012). Transfer of active learning strategies from the teacher education classroom to Pre-K 12th grade classrooms. Current issues in Education, Vol. 15, N. 3,pp.1-23. 
Peters, J. (2006). Engaging student teachers through the development and presentation of problem-based scenarios. Paper presented at the AARE Conference, Adelaide

Savery, J. \& Duffy, T. (1995). Problem-based learning: An instructional model and its constructivist framework. Educational Technology, Vol.35, pp.31-38

Spratt, M.; Pulverness, A. \& Williams, M. (2011).The Teaching Knowledge Test Course(TKT). $2^{\text {nd }}$ ed. United Kigdom: CAMBRIDGE university press

Stronge, J. (2007). Qualities of effective teachers. $2^{\text {nd }}$ ed. USA: Association for Supervision and Curriculum Development (ASCD)

Taha, A. (2017). The impact of Action Research based projects on developing student teachers; EFL teaching knowledge and performance. MA. Thesis, Faculty of Education, Mansoura University

Toulouse, K., Spaziani, R. \& Rangachari, P. (2012). A Backward Glance, the Forward Gaze: Evaluation in Problem-Based Courses. In Bridges, S.; McGrath, C. \& Whitehill, T. (2012). Problem-Based Learning in Clinical Education: The Next Generation. London: Springer Dordrecht Heidelberg

Vogel, A. (2014). Impact of a problem-based learning curriculum on pre-service teacher development. Ph.D. Dissertation. University of Wisconsin-Madison, Proquest UMI N.3624742

Walker, A. \& Leary, H. (2009). A problem-based learning metaanalysis: Differences across problems types, implementation types, disciplines, and asses sment levels. Interdisciplinary Journal of Problem-Based Learning, Vol.3, N. 1, pp. 12-43

Weinstein, C. \& Weber, W. (2011). Classroom Management. In Cooper, J. (2011). Classroom Teaching Skills, Ninth Edition. USA: Wadsworth, Cengage Learning 